\title{
Method for estimating soil carbon stock changes in Finnish mineral cropland and grassland soils
}

\author{
Taru Palosuo $^{1, *}$, Jaakko Heikkinen ${ }^{2}$ and Kristiina Regina ${ }^{2}$ \\ ${ }^{1}$ Natural Resources Institute Finland (Luke), 01370 Vantaa, Finland; \\ ${ }^{2}$ Natural Resources Institute Finland (Luke), 31600 Jokioinen, Finland
}

*Corresponding author. Email: taru.palosuo@luke.fi

Carbon Management 2016 


\section{Figure S1}
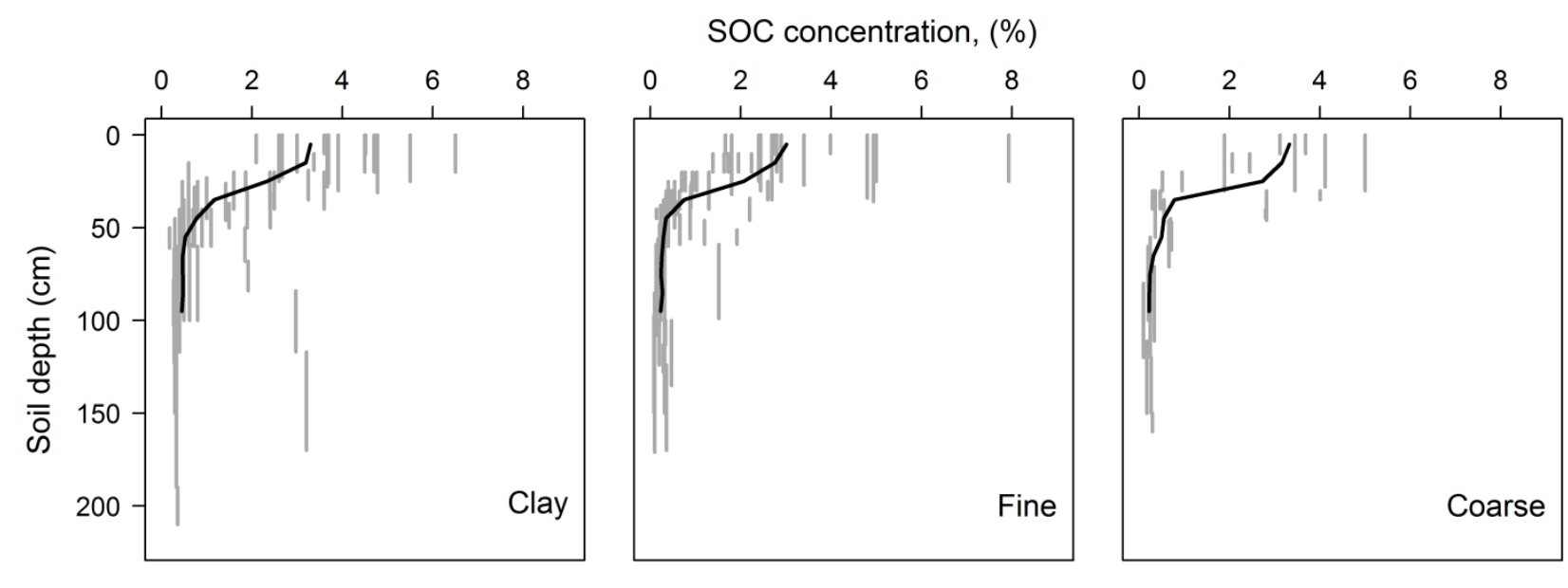

Figure S1 Literature review of 14 studies and 68 sites in Finland (references listed below) was conducted to estimate the share of SOC in soil layers below $15 \mathrm{~cm}$. Sites were classified based on the soil type for clay (clay content>30\%, $n=30$ ), fine (dominant particle size $<0.06 \mathrm{~mm}, \mathrm{n}=22$ ) and coarse soils (dominat particle size $>0.06 \mathrm{~mm}, \mathrm{n}=16$ ). Soil C concentration within the profile (black line) was modelled using linear mixed effect model, in which soil type, soil layer (in $10 \mathrm{~cm}$ interval) and their interaction were as fixed-effects and the site as a random effect. Soil $\mathrm{C}$ concentrations were log-transformed. SOC concentrations were taken as a proxy for SOC amounts by assuming constant bulk density over the depth profile. The estimated share of SOC below $15 \mathrm{~cm}$ were $63 \%, 57 \%$ and $59 \%$ for clay, fine and coarse soils, accordingly. Grey lines show the original measurements.

\section{References:}

Alakukku, Laura. 1996a. "Persistence of Soil Compaction due to High Axle Load Traffic. I. ShortTerm Effects on the Properties of Clay and Organic Soils." Soil and Tillage Research 37 (4): 211222.

1996b. "Persistence of Soil Compaction due to High Axle Load Traffic. II. Long-Term Effects on the Properties of Fine-Textured and Organic Soils." Soil and Tillage Research 37 (4): 223-238. 
Alakukku, Laura, Visa Nuutinen, Elise Ketoja, Harri Koivusalo, and Maija Paasonen-Kivekäs. 2010. "Soil Macroporosity in Relation to Subsurface Drain Location on a Sloping Clay Field in Humid Climatic Conditions." Soil and Tillage Research 106 (2): 275-284.

Joukainen, Sirpa and Markku Yli-Halla. 2003. "Environmental Impacts and Acid Loads from Deep Sulfidic Layers of Two Well-Drained Acid Sulfate Soils in Western Finland." Agriculture, Ecosystems \& Environment 95 (1): 297-309.

Kaasalainen, Marika and Markku Yli-Halla. 2003. "Use of Sequential Extraction to Assess Metal Partitioning in Soils." Environmental Pollution 126 (2): 225-233.

Paasonen-Kivekäs, Maija and Markku Yli-Halla. 2008. "A Comparison of Nitrogen and Carbon Reserves in Acid Sulphate and Non Acid Sulphate Soils in Western Finland." Agricultural and Food Science 14 (1): 57-69.

Peltovuori, Tommi, Risto Uusitalo, and Tommi Kauppila. 2002. "Phosphorus Reserves and Apparent Phosphorus Saturation in Four Weakly Developed Cultivated Pedons." Geoderma 110 (1): 35-47.

Räty, Mari, Rainer Horn, and Kimmo Rasa. 2008. "Compressive Behaviour of the Soil in Buffer Zones Under Different Management Practices in Finland." Agricultural and Food Science 19 (2): 160-172.

Turtola, Eila and Erkki Kemppainen. 2008. "Nitrogen and Phosphorus Losses in Surface Runoff and Drainage Water After Application of Slurry and Mineral Fertilizer to Perennial Grass Ley." Agricultural and Food Science 7 (5-6): 569-581.

Turtola, Eila and Arja Paajanen. 1995. "Influence of Improved Subsurface Drainage on Phosphorus Losses and Nitrogen Leaching from a Heavy Clay Soil." Agricultural Water Management 28 (4): 295-310.

Turtola, Eila and Markku Yli-Halla. 1999. "Fate of Phosphorus Applied in Slurry and Mineral Fertilizer: Accumulation in Soil and Release into Surface Runoff Water." Nutrient Cycling in Agroecosystems 55 (2): 165-174.

Yli-Halla, Markku, D. L. Mokma, T. Peltovuori, and Jouko Sippola. 2000. Suomalaisia Maaprofiileja [Agricultural Soil Profiles in Finland and their Classification], in Finnish. Jokioinen: Maatalouden tutkimuskeskus.

Yli-Halla, Markku and Delbert L. Mokma. 2008. "Soils in an Agricultural Landscape of Jokioinen, South-Western Finland." Agricultural and Food Science 10 (1): 33-43.

Yli-Halla, Markku, Delbert L. Mokma, and Lawrence P. Wilding. 2008. "Formation of a Cultivated Spodosol in East-Central Finland." Agricultural and Food Science 15 (1): 12-22. 


\section{Figure S2}

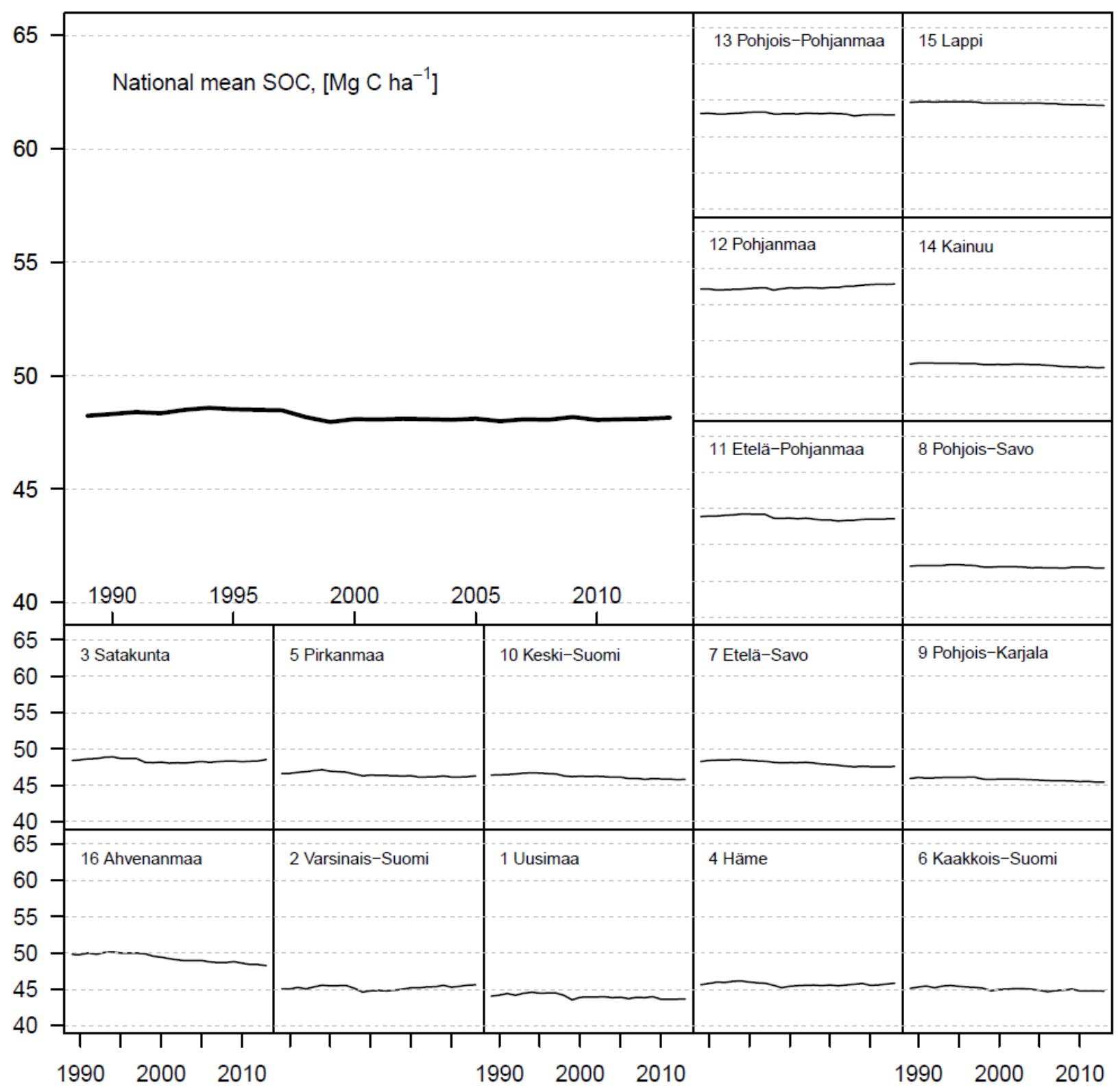

Figure S2. Simulated dynamics of the SOC stock $\left[\mathrm{Mg} \mathrm{C} \mathrm{ha}^{-1}\right]$ for Cropland remaining cropland as the national mean (large cell) and separately for each regional ELY Centres (small cells). These simulations were done using mean climate data of the period 1961-2013 and annual litter and manure $\mathrm{C}$ inputs. The initialisation was done using the same mean climate data and litter input of 1990-1999 to run the model to steady state. 
Figure S3

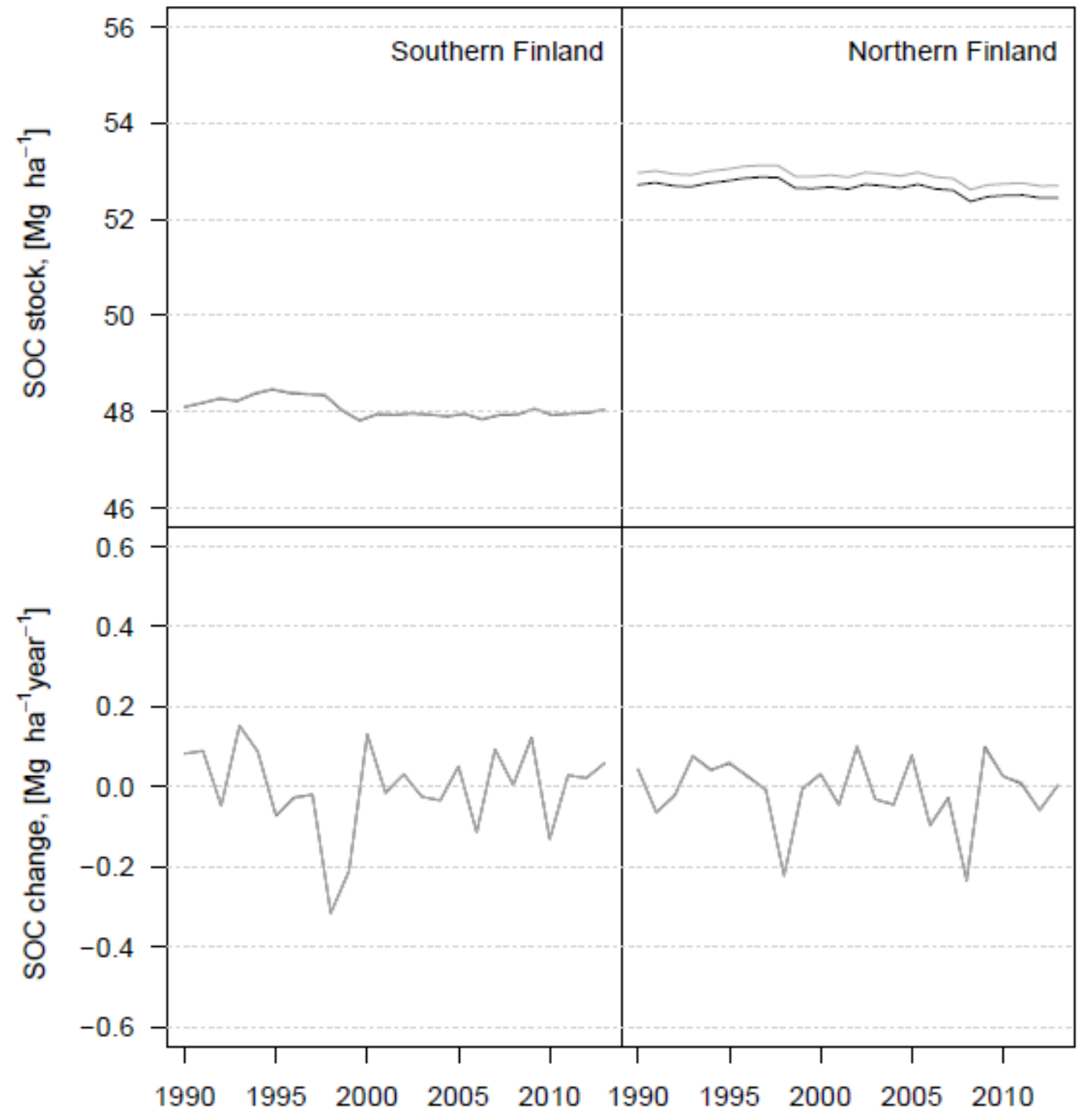

Figure S3. SOC stocks and stock changes of CRC for Southern and Northern Finland calculated based on ELY Centre level simulations (black line) and simulations done based on aggregated input for these subnational regions (grey lines). 


\section{Figure S4}

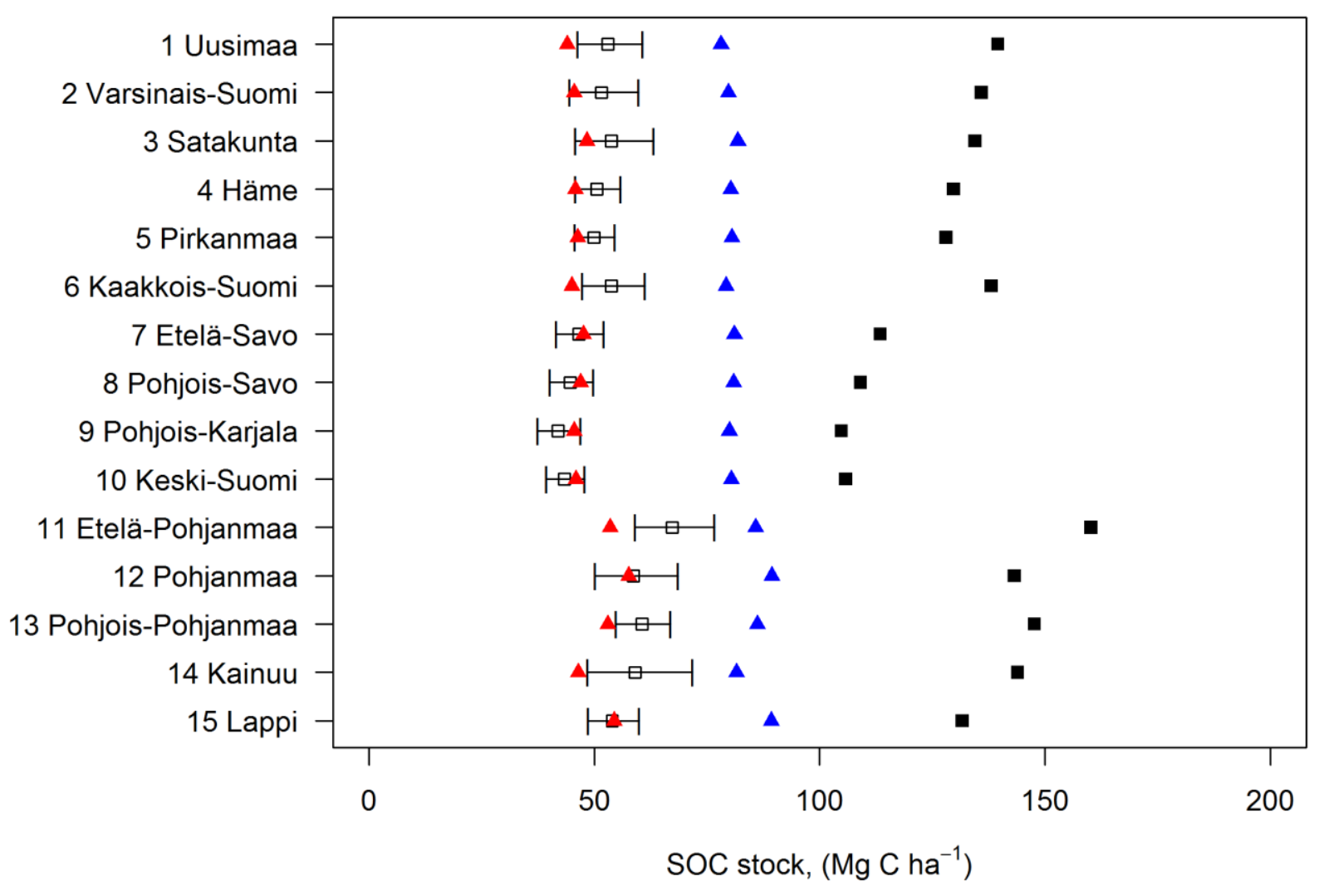

Figure S4 Comparison of SOC stocks at ELY centres in 2009. The open black squares show the observed mean stocks to the depth of $15 \mathrm{~cm}$ with $95 \%$ confidence intervals based on the national soil monitoring network (Heikkinen et al. (2013). The black boxes show the same observations scaled to the layer of $1 \mathrm{~m}$ depth with the help of SOC density functions in Fig. S1. The red and blue triangels mark the simulated SOC stocks to the depth of $1 \mathrm{~m}$ calculated using initialisation with agricultural litter input and initialisation with estimated SOC stock of forests for 1900 and pre-running the model for a period of 90 years with agricultural litter input, accordingly. 